\title{
PERFORMANCE AND SEED QUALITY OF MOROCCAN SUNFLOWER VARIETIES ANDSPANISH LANDRACES USED FOR CONFECTIONERY AND SNACK FOOD
}

\author{
Nabloussi, A. ${ }^{1}$, Fernández-Cuesta, Á. ${ }^{2}$, El-Fechtali, M. ${ }^{1}$, \\ Fernández-Martínez, J.M. ${ }^{2}$, Velasco, L. ${ }^{2 *}$ \\ ${ }^{1}$ INRA-CRRA, P.O. Box 578, 50000 Meknès, Morocco \\ ${ }^{2}$ Instituto de Agricultura Sostenible (CSIC), Alameda del Obispo s/n, \\ E-14004 Córdoba, Spain
}

Received: November 15, 2011 Accepted: December 10, 2011

\section{SUMMARY}

Sunflower seeds are one of the most important sources of vegetable oil in the world. Additionally, they are used for confectionery and snack food, as well as for bird and pet food. Sunflower germplasm used for food differs between Morocco and Spain. Whereas sunflower seeds used for food in Morocco are mainly obtained from oilseed-type cultivars with black achenes and low hull proportion, those used in Spain derive from confectionery-type cultivars with black and white striped achenes and high hull proportion. The objective of this research was to evaluate the performance and seed quality of Moroccan and Spanish sunflower germplasm used for food. Six cultivars from Morocco and six landraces from Spain were evaluated in replicated field trials in Ain Taoujdate (Morocco) and Córdoba (Spain) in 2009. Seed yield, hundred-achene weight, hundred-kernel weight, achene oil content, kernel oil content, and fatty acid profile were measured. The results showed that confectionery-type and oilseed-type cultivars did not differ in seed yield, hundred-kernel weight and kernel oil content. Since confectionery-type cultivars from Spain performed similarly to local oilseed-type cultivars, they could be introduced to diversify the offer of in-shell sunflower seed snack in Morocco.

Key words: confectionery cultivars, fatty acids, Morocco, oil content, oilseedtype cultivars, Spain, sunflower, yield

\section{INTRODUCTION}

Around $10 \%$ of the sunflower seed produced annually in the world is used for non-oil purposes, mainly for confectionery and snack food, as well as for bird and pet food (National Sunflower Association, 2011). Sunflower seeds entering non-oil markets derive from both confectionery-type and oilseed-type cultivars. Confection-

* Corresponding author. Phone: +34-957-499236; Fax: +34-957-499252;

e-mail: lvelasco@ias.csic.es 
ery-type cultivars are characterized by large achenes that have black (or grey) and white stripes and contain a high hull percentage. Oilseed-type cultivars produce smaller black achenes with low hull content (Fernández-Martínez et al., 2009). Seeds from confectionery cultivars are separated into three grades based on size. The largest seeds are marketed unhulled (in-shell), salted and roasted to be consumed as a snack food. Medium-size seeds are hulled and the kernels are mainly used for confectionery and bakery products. Finally, smaller seeds are mainly intended for feeding wild birds and pets (Lofgren, 1997).

Spain is the largest importer of in-shell confectionery sunflower seeds. The country has a long tradition of consuming them as a snack food, but the national production dropped drastically after admission into the EU, due to the EU Common Agricultural Policy which limits the production subsidy to oilseed-type sunflower (Kleingartner, 1997). Production was maintained at a small scale, mainly based on local landraces. Spanish customers mainly demand confectionery-type inshell seeds (Lofgren, 1997). Turkey (Kaya, 2004) and China (Zhang, 2004) are also countries in which there is large consumption of confectionery-type seeds as a snack food. Conversely, customers in other countries such as those in the Balkan region and Russia prefer in-shell black seeds (Kaya, 2004). The latter is also the case for Morocco, where most of the sunflower seeds in local markets are of the oilseed type (El Asri et al., 2006). However, confectionery-type seeds can also be found in local markets of Morocco.

Production of confectionery-type seed, in addition to oilseed-type seed, could be advantageous for local farmers in Morocco. Due to the limited availability of confectionery cultivars, evaluation of Spanish cultivars is an interesting approach to initiate the selection of materials adapted to the local Moroccan environments. Accordingly, the objective of this research was to evaluate the performance and seed quality of a representative group of confectionery-type sunflower landraces from Spain, together with oilseed-type cultivars currently used for snack food in Morocco.

\section{MATERIALS AND METHODS}

The study was based on six cultivars from Spain and six cultivars from Morocco. All of them were open-pollinated cultivars with high degree of self-incompatibility. Spanish cultivars were in all cases local landraces collected in small farmers' fields. They were B-2, B-96 and B-107 collected in Córdoba province, B132 collected in Jaén province, B-146 collected in Granada province, and B-307 collected in Cuenca province. All the Spanish cultivars were of the confectionery type, i.e., they have large black and white striped achenes with high hull content. Cultivars from Morocco were Karima, Oukrania, Peredovik, Salima, and Znatia. Karima and Salima were released by INRA-Morocco (Nabloussi et al., 2005). Peredovik is an old Russian cultivar widely cultivated in Morocco. Oukrania and Znatia 
are local varieties collected in Kenitra province. These cultivars are of the oilseed type, i.e., they have black seeds with a low hull proportion. However, seeds from them are widely sold as in-shell snack food in local markets. Additionally, the confectionery-type cultivar MK-1 with striped achenes was used. Its origin is unknown, but it is likely to derive from Spain as the seeds were collected in a local market in Larache province in the north of Morocco, where the farmers cultivate confectionery-type cultivars introduced from Spain.

Plants of the 12 cultivars were grown in the field in the experimental farm of the Instituto de Agricultura Sostenible at Córdoba, Spain, and the experimental farm of the Institut National de la Recherche Agronomique at Aïn Taoujdate, Morocco in 2009. The plants were grown in replicated trials with three replications. Plots of each cultivar consisted of four rows $5 \mathrm{~m}$ long with $60 \mathrm{~cm}$ spacing between rows. The heads of 12 plants of the two central rows were bagged with mesh bags after flowering to protect them from bird damage. The plants were harvested at maturity. Seed yield, hundred achene weight and achene oil content were measured. Furthermore, fifty achenes per replication were randomly chosen and hulled and the kernel and hull proportions were determined. For oil content analysis, around fifty achenes were desiccated during 2 hours at $105^{\circ} \mathrm{C}$ in a convection oven and then maintained in a desiccator for one hour. Desiccated achenes were weighted and their oil content was measured by nuclear magnetic resonance (NMR) on an Oxford 4000 analyzer (Oxford Analytical Instruments Ltd., Abingdon, OX, United Kingdom).

The fatty acid composition of the seed oil of 12 individual seed kernels per plant was analyzed by simultaneous extraction and methylation (Garcés and Mancha, 1993) followed by gas-liquid chromatography (GLC) using a Perkin-Elmer Autosystem gas-liquid chromatograph (Perkin-Elmer Corporation, Norwalk, CT, USA). A 2 m long column packed with 3\% SP-2310/2\% SP-2300 on Chromosorb WAW (Supelco Inc., Bellefonte, PA, USA) was used. The oven, injector and flame ionization detector were held at 195,275 and $250^{\circ} \mathrm{C}$, respectively.

Data were analysed by the General Linear Model procedure of IBM SPSS Statistics version 19.0 (IBM Corp., Armonk, NY, USA). Analysis of variance was performed with genotypes as fixed factor and location as random factor. Comparison of the means was performed by independent t-tests.

\section{RESULTS AND DISCUSSION}

The analysis of variance considering genotypes, locations and their interaction as factors showed that variation for seed yield was mainly associated to the effect of locations, with no significant effect of genotypes or genotype $\times$ location interaction (Table 1). This is in agreement with the low heritability of a complex trait such as seed yield (Cecconi and Baldini, 1991). Both achene oil content and kernel oil content were influenced by the genotype $\times$ location interaction, with no significant 
effect of genotypes or locations. Conversely, no significant effect of the interaction was detected for hundred-achene weight and hundred-kernel weight, for which the effect of locations was predominant. Variation for hull content was mainly influenced by the genotype and the genotype $\times$ location interaction, though the location effect was also significant. Hull content in sunflower is a quantitative trait with high heritability mainly governed by genes with additive effects (Kovačik and Škaloud, 1990). Finally, the analysis of variance showed a pronounced effect of the location on the fatty acid profile, with the genotype $\times$ location interaction being only significant for stearic acid and linoleic acid content (Table 1). Previous studies have emphasized the influence of the environment on the fatty acid content of sunflower seed oil, particularly on oleic acid and linoleic acid content (Canvin, 1965; Echarte et al., 2010).

Table 1: Analysis of variance (mean squares) for seed yield $\left(\mathrm{kg} \mathrm{ha}^{-1}\right)$, achene oil content (\%), kernel oil content (\%), hundred achene weight (HAW, g), hundred kernel weight (HKW, g), hull content (\%), and percentages of palmitic acid (16:0), stearic acid (18:0), oleic acid (18:1) and linoleic acid (\%) in seven confectionery-type cultivars and five oilseed-type cultivars grown in Córdoba, Spain and Aïn Taoujdate, Morocco in 2009.

\begin{tabular}{|c|c|c|c|c|c|c|c|c|c|c|c|}
\hline & df & Yield & Ach oil & Ker oil & HAW & HKW & Hull & 16:0 & 18:0 & 18:1 & 18:2 \\
\hline Genotype (G) & 11 & $507312 \mathrm{~ns}$ & $111 \mathrm{~ns}$ & $117 \mathrm{~ns}$ & $5.6^{*}$ & $0.6 \mathrm{~ns}$ & 293 ** & $0.3 \mathrm{~ns}$ & $0.8 \mathrm{~ns}$ & $90 \mathrm{~ns}$ & $93 \mathrm{~ns}$ \\
\hline Location & 1 & 23321472 ** & $24 \mathrm{~ns}$ & 314 ns & $21.5^{* *}$ & $18.1^{\text {** }}$ & 123 * & $11.2^{* \star}$ & 15.1 ** & 1065 ** & 1096 ** \\
\hline$G \times L^{1}$ & 8 & 288427 ns & $43^{* *}$ & 98 ** & $1.6 \mathrm{~ns}$ & $1.4 \mathrm{~ns}$ & 22 ** & $0.2 \mathrm{~ns}$ & $0.9 * *$ & $29 \mathrm{~ns}$ & 37 * \\
\hline
\end{tabular}

${ }^{1}$ Due to a significant number of diseased plants, cultivars B-2 and B-132 were discarded in Córdoba and cultivar B-146 was discarded in Aïn Taoujdate.

Confectionery-type and oilseed-type cultivars did not differ for average seed yield neither in Spain nor in Morocco (Table 2). For the whole set of cultivars, average seed yield in Spain was more than two-fold the average seed yield in Morocco, due to more favourable environmental conditions. As expected, confectionery-type cultivars had significantly lower achene oil content and higher hull content than oilseed-type cultivars, both in Spain and Morocco. Interestingly, both types of cultivars did not differ for kernel oil content (Table 2), which is in agreement with previous reports (Buendia and D'Appolonia, 1986). Confectionery-type cultivars had higher hundred-achene weight than oilseed-type cultivars in Spain, but differences between both types of cultivars were not significant in Morocco. Hundred-kernel weight did not differ significantly between both types of cultivars in any environment. Stearic acid content differed between confectionery-type and oilseed-type cultivars in both environment, but in different directions, i.e., oilseed-type cultivars showed higher stearic acid content in Spain but lower stearic acid content in Morocco (Table 2). This is consistent with the significant genotype $\mathrm{x}$ location interaction detected for this fatty acid in the analysis of variance (Table 1). Differences for oleic acid and linoleic acid content were significant only in Morocco. Seeds from plants grown in Spain had higher oleic acid content and lower linoleic acid content than plants grown in Morocco (Table 2), which was probably attributable to differ- 
ences in the minimum daily temperature, which averaged $18.4^{\circ} \mathrm{C}$ during the seed filling period in the location in Spain and $16.8^{\circ} \mathrm{C}$ in the location in Morocco. Echarte et al. (2010) found that small changes of minimum temperature in the range from around 15 to $25^{\circ} \mathrm{C}$ produced large changes in oleic acid content and concomitantly in the levels of other fatty acids, in such a way that reduced temperature were associated with reduced oleic acid content.

Table 2: Average seed yield ( $\left.\mathrm{kg} \mathrm{ha}^{-1}\right)$, achene oil content (\%), kernel oil content (\%), hundred achene weight (HAW, g), hundred kernel weight (HKW, g), hull content (\%), and percentages of palmitic acid (16:0), stearic acid (18:0), oleic acid (18:1) and linoleic acid (\%) in seven confectionery-type cultivars and five oilseed-type cultivars grown in Córdoba, Spain and Aïn Taoujdate, Morocco in 2009.

\begin{tabular}{|c|c|c|c|c|c|c|c|c|c|c|}
\hline Type & Yield & Ach oil & Ker oil & HAW & HKW & Hull & $16: 0$ & 18:0 & $18: 1$ & $18: 2$ \\
\hline & \multicolumn{10}{|c|}{ Córdoba } \\
\hline Confectionery & 2540 & 30.6 & 51.6 & 8.7 & 5.1 & 40.3 & 6.3 & 3.9 & 43.1 & 46.8 \\
\hline \multirow[t]{2}{*}{ Oilseed $^{1}$} & $2632 \mathrm{~ns}$ & 37.2 ** & $51.9 \mathrm{~ns}$ & $6.7 * *$ & $4.8 \mathrm{~ns}$ & 28.4 ** & $6.5 \mathrm{~ns}$ & $4.5 * *$ & $41.6 \mathrm{~ns}$ & $47.4 \mathrm{~ns}$ \\
\hline & \multicolumn{10}{|c|}{ Aïn Taoujdate } \\
\hline Confectionery & 1285 & 30.8 & 56.6 & 6.6 & 3.6 & 45.0 & 7.3 & 3.6 & 37.6 & 51.4 \\
\hline Oilseed $^{1}$ & $1158 \mathrm{~ns}$ & 38.3 ** & $54.6 \mathrm{~ns}$ & $5.6 \mathrm{~ns}$ & $3.9 \mathrm{~ns}$ & 29.6 ** & $7.3 \mathrm{~ns}$ & 2.8 ** & 30.3 ** & 59.6 ** \\
\hline
\end{tabular}

${ }^{1}$ Comparison of means was performed within each location by independent $t$-tests. ns $=$ not significant, ${ }^{*}=$ significant at $p<0.05,{ }^{* *}=$ significant at $p<0.01$

Some traits were correlated in one environment, but not in the other. In order to focus on consistent correlations, only those that were significant and in the same direction in both environments will be considered. Seed yield positively correlated with both hundred-achene weight $(\mathrm{r}=0.37, \mathrm{P}<0.05$ in Spain; $\mathrm{r}=0.60, \mathrm{P}<0.01$ in Morocco) and hundred-kernel weight $(r=0.61, P<0.01$ in Spain; $r=0.73, P<0.01$ in Morocco). The two latter were in turn positively correlated to each other $(r=0.74$, $\mathrm{P}<0.01$ in Spain; $\mathrm{r}=0.84, \mathrm{P}<0.01$ in Morocco). Significant positive correlations between seed yield and seed weight have been reported by many authors (Miller and Fick, 1997). Hundred-achene weight was also positively correlated with hull content $(\mathrm{r}=0.77, \mathrm{P}<0.01$ in Spain; $\mathrm{r}=0.34, \mathrm{P}<0.01$ in Morocco). A significant negative correlation of palmitic acid content with both hundred-achene weight $(r=-0.37$, $\mathrm{P}<0.05$ in Spain; $\mathrm{r}=-0.50, \mathrm{P}<0.01$ in Morocco) and hundred-kernel weight $(\mathrm{r}=$ $0.48, \mathrm{P}<0.01$ in Spain; $\mathrm{r}=-0.62, \mathrm{P}<0.01$ in Morocco) was identified, though the biological meaning of such a correlation is unknown. Achene oil content negatively correlated with both hundred-achene weight $(r=-0.65, P<0.01$ in Spain; $r=-0.25$, $\mathrm{P}<0.05$ in Morocco) and hull content $(\mathrm{r}=-0.92, \mathrm{P}<0.01$ in Spain; $\mathrm{r}=-0.62, \mathrm{P}<0.01$ in Morocco). With regard to the fatty acid profile, significant negative correlations involved palmitic acid and oleic acid $(\mathrm{r}=-0.38, \mathrm{P}<0.05$ in Spain; $\mathrm{r}=-0.62, \mathrm{P}<0.01$ in Morocco) and oleic acid and linoleic acid ( $\mathrm{r}=-0.98, \mathrm{P}<0.01$ in Spain; $\mathrm{r}=-0.99$, $\mathrm{P}<0.01$ in Morocco). Similar correlations between sunflower fatty acids have been previously reported (Zimmerman \& Fick, 1973; George et al., 1988).

Oilseed-type cultivars with black achenes and low hull proportion are predominantly used for confectionery and snack food in Morocco, whereas confectionery- 
type cultivars with black and white striped achenes and high hull proportion predominate in Spain. The results of the present research revealed that both types of cultivars did not differ for seed yield, hundred-kernel weight or kernel oil content. Because confectionery-type cultivars from Spain performed similarly to local oilseed-type cultivars in Morocco, they could be introduced in this country to diversify the offer of in-shell sunflower seed snack for local markets.

\title{
ACKNOWLEDGMENTS
}

\begin{abstract}
The research was partially supported by Consejo Superior de Investigaciones Científicas (CSIC), Spain and Centre National pour la Recherche Scientifique et Technique (CNRST), Morocco, project number 2007 MAOO59.
\end{abstract}

\section{REFERENCES}

Buendia, M.O. and D'Appolonia, B.L., 1986. Storage studies on confectionery sunflower kernels. Cereal Chem. 63: 85-88.

Canvin, D.T., 1965. The effect of temperature on the oil content and fatty acid composition of the oils from several oilseed crops. Can. J. Bot. 43: 63-69.

Cecconi, F. and Baldini, M., 1991. Genetic analysis of some physiological characters in relation to plant development of a sunflower (Helianthus annuus L.) diallel cross. Helia 14: 93100.

Echarte, M.M., Angeloni, P., Jaimes, F., Tognetti, J., Izquierdo, N.G., Valentinuz, O. and Aguirrezábal, L.A.N., 2010. Night temperature and intercepted solar radiation additively contribute to oleic acid percentage in sunflower oil. Field Crops Res. 119: 27-35.

El Asri, M., Nabloussi, A., Essahat, A., El Fechtali, M. and Alghoum, M., 2006. Enquête sur l'autoproduction des semences de tournesol et la collecte de populations locales au Maroc (zone du Gharb). Al Awamia 118/119: 86-102.

Fernández-Martínez, J.M., Perez-Vich, B. and Velasco, L., 2009. Sunflower. In: Vollmann, J. and Rajčan, I. (Eds.) Oil Crop Breeding, Springer, New York (USA), pp. 155-232.

Garcés, R. and Mancha, M., 1993. One-step lipid extraction and fatty acid methyl esters preparation from fresh plant tissues. Anal. Biochem. 211: 139-143.

George, D.L., McLeod, C.M. and Simpson, B.W., 1988. Effect of seed position on fatty acid content in sunflower (Helianthus annuus L.). Aust. J. Exp. Agric. 28: 629-633.

Kaya, Y., 2004. Confectionery sunflower production in Turkey. In: Proceedings of the $16^{\text {th }}$ International Sunflower Conference, Fargo, ND, USA, pp. 817-822.

Kleingartner, L.W., 1997. The world oilseed environment. In: Schneiter, A.A. (Ed.), Sunflower Technology and Production, American Society of Agronomy, Madison, WI (USA), pp. 809824.

Kovačik, A. and Škaloud, V., 1990. Results of inheritance evaluation of agronomically important traits in sunflower. Helia 13: 41-46.

Lofgren, J.R., 1997. Sunflower for confectionery food, bird food, and pet food. In: Schneiter, A.A. (Ed.), Sunflower Technology and Production, American Society of Agronomy, Madison, WI (USA), pp. 747-764.

Miller, J.F. and Fick, G.N., 1997. The genetics of sunflower. In: Schneiter, A.A. (Ed.), Sunflower Technology and Production, American Society of Agronomy, Madison, WI, USA, pp. 441495.

Nabloussi, A., El Asri, M., Akhtouch, B., Gosset, H., El Fechtali, M. and Alghoum, M., 2005. Amélioration génétique du tournesol. In: Abbad Andaloussi, F. and A. Chahbar (Eds.), La Creation Variétale à l'INRA: Méthodologie, Acquis et Perspectives. Institut Nationale de la Recherche Agronomique, Rabat, Morocco, pp. 237-252. 
National Sunflower Association, 2011. Sunflower Statistics. World Supply and Disappearance. Retrieved August 30, 2011 from: http://www.sunflowernsa.com/stats/world-supply/.

Zhang, H., 2004. Sunflower needed by the Chinese market. In: Proceedings of the $16^{\text {th }}$ International Sunflower Conference, Fargo, ND, USA, pp. 823-826.

Zimmerman, D.C. and Fick, G.N., 1973. Fatty acid composition of sunflower (Helianthus annuus L.) oil as influenced by seed position. J. Am. Oil Chem. Soc. 50: 273-275.

\title{
RENDIMIENTO Y CALIDAD DE SEMILLA DE VARIEDADES MARROQUÍES DE GIRASOL Y RAZAS LOCALES ESPAÑOLAS EMPLEADAS EN CONFITERÍA Y PARA CONSUMO DIRECTO
}

\author{
RESUMEN
}

Las semillas de girasol representan una de las principales fuentes de aceite vegetal en el mundo. Asimismo, se emplean también para elaboración de productos de panadería y pastelería, para consumo directo como aperitivo, y para alimentación de mascotas. El germoplasma de girasol empleado para estos fines difiere entre Marruecos y España. Mientras que en Marruecos la semilla de girasol empleada para consumo directo procede principalmente de cultivares de tipo oleaginoso, con aquenios negros y baja proporción de cáscara, en España se obtiene principalmente de cultivares de pipa blanca con una elevada proporción de cáscara. El objetivo de este trabajo fue evaluar el comportamiento y la calidad de la semilla de germoplasma de girasol de Marruecos y España usado con fines no oleaginosos. Se ensayaron en campo en 2009 seis cultivares de Marruecos y seis cultivares de España, tanto en Aïn Taoujdate (Marruecos) como en Córdoba (España). Se determino el rendimiento de semilla, el peso de 100 aquenios, el peso de 100 semillas, el contenido en aceite en aquenios y semillas, y la composición en ácidos grasos del aceite. No se encontraron diferencias para rendimiento, peso de 100 semillas, y contenido en aceite en la semillas entre cultivares de pipa blanca y cultivares de tipo oleaginoso. Puesto que los cultivares de pipa blanca de España tuvieron un rendimiento similar a los cultivares locales oleaginosos, podría plantearse su introducción para ampliar la oferta de tipos de semilla de girasol vendida para consumo directo en Marruecos.

\section{PERFORMANCE ET QUALITE DES GRAINES DE VARIETES MAROCAINES ET DE VARIETES LOCALES ESPAGNOLES UTILISEES POUR LA CONFISERIE ET LE TOURNESOL DE BOUCHE}

\author{
RESUME
}

Les graines de tournesol constituent une des principales sources d'huile végétale dans le monde. Elles sont aussi utilisées pour la confiserie et directement comme graines de bouche, ainsi que pour l'alimentation des oiseaux et des animaux. Le germoplasme de tournesol utilisé pour ces fins au Maroc et en Espagne est différent. En Espagne, ce sont les cultivars de confiserie, caractérisés par des achènes blanches à rayures noires ou grises avec une proportion élevée de coquille, qui sont utilisés, alors qu'au Maroc, on utilise plutôt les cultivars de type oléagineux, ayant des achènes noires avec une faible proportion de coquille. Lobjectif de cette étude est d'évaluer la performance et la qual- 
ité des graines de germoplasme marocain et espagnol utilisé pour des fins non oléagineuses. En 2009, six cultivars de Maroc et six cultivars d'Espagne ont été évalués en essai au champ, aussi bien au Maroc (Aïn Taoujdate) qu'en Espagne (Cordoue). Les paramètres mesurés ont été le rendement grain, le poids de 100 achènes, le poids de 100 graines, la teneur en huile des achènes et des graines et la composition d'acides gras de l'huile. Les résultats ont montré qu'il n'y avait pas de différence significative entre les cultivars de confiserie et les cultivars de type oléagineux pour le rendement grain, le poids de 100 graines et la teneur en huile des graines. Etant donné que les cultivars de confiserie d'Espagne ont eu un rendement comparable à celui des cultivars oléagineux locaux, ils pourraient être introduits au Maroc afin de diversifier l'offre de types de graines dans le marché du tournesol de bouche. 